\title{
Komunikasi Organisasi Dinas Kesehatan dalam Program Eliminasi
}

\section{Malaria}

\author{
Sihabuddin ${ }^{1}$, Widodo Muktiyo, Sudarmo \\ b.sihabuddin@yahoo.co.id, muktiyo@yahoo.com, sudarmo63@yahoo.com
}

\begin{abstract}
Abstrak
Latar belakang penelitian ini adalah kesuksesan Dinas Kesehatan Provinsi Jawa Timur dalam program eliminasi malaria sehingga pada tahun 2015 Provinsi Jawa Timur mendapatkan sertifikasi eliminasi malaria (kecuali tiga Kabupaten namun sudah diusulkan). Program eliminasi malaria adalah program untuk menghentikan penularan penyakit malaria setempat agar tidak menimbulkan semakin banyak korban, program ini dicanangkan oleh Kementrian Kesehatan Republik Indonesia. Penelitian ini bertujuan untuk menggambarkan dan menganalisa kewenangan, spesialisasi/pengkhususan dan peraturan komunikasi organisasi antara Dinas Kesehatan Provinsi dan Kabupaten/Kota di Jawa Timur, juga untuk menggambarkan dan menganalisa pembuatan, pemilihan, dan penyimpanan informasi dalam komunikasi organisasi pada program eliminasi malaria antara Dinas Kesehatan Provinsi dan Kabupaten/Kota di Jawa Timur. Adapun metode yang digunakan dalam penelitian ini yaitu deskriptif kualitatif dengan format studi kasus dengan teknik pengumpulan data wawancara mendalam dan metode dokumenter. Hasil penelitian bahwasanya kesuksesan program eliminasi malaria di Provinsi Jawa Timur tidak lepas dari pengorganisasian yang dilakukan dengan tiga komponen yaitu kewenangan, spesialisasi/pengkhususan, dan peraturan yang berjalan sebagai mana mestinya. Hal ini dikarenakan kepatuhan dan pemahaman semua komponen pelaku organisasi program eliminasi malaria di Dinas Kesehatan Provinsi Jawa Timur terhadap komponen tersebut. Selain itu, dalam mengolah, memilih atau menyaring, dan menyimpan informasi dari Dinas Kesehatan Kabupaten/Kota dilakukan dengan hati-hati oleh Dinas Kesehatan Provinsi sebagai induk dari Dinas Kesehatan Kabupaten/Kota di Jawa Timur.
\end{abstract}

Kata Kunci: Kesehatan, Komunikasi, Malaria, Organisasi, Program

\begin{abstract}
The background of this reasearch is the succeses of Provincial Health Office of East Java ini malaria elemination program that brings all districts/ cities at East Java obtain certification of malaria elemination in 2015 (except the tree districts but it has been proposed). Malaria elimination program is a national program launched by the Ministry of Health of the Republic of Indonesia to stop the transmission of local malaria so that there is no more casualities. The purpose of this research is to describe and analyze the autority, specialization and regulation of organizayional communication between the Provincial Health Office and District/ City at East Java, as well as to describe and analyze the manufacture, selection, and retention of information in organizational communication between the Provincial Health Office and District/ City at East Java in the malaria elimination program. This is a descriptive and qualitative research that using interviews and documentary methods. The results of the reserch was the succes of malaria elimination program at East Java province cound not be separated from the organizing that carried out with three components which are authority, specialization, and regulations that runs as it should be. This is because of the compliance and understanding of all components of malaria elimination program organization at East Java Provincial Health
\end{abstract}

${ }^{1}$ Korespondensi: Sihabuddin. Program Studi Magister Ilmu Komunikasi. Universitas Sebelas Maret, Jl. Ir. Sutami 36A, Surakarta 57126, Telp. (0271) 663483. 
Office of those components. Moreover, in manufacturing, selecting, and storing information from the District / City Health Office was done with great caution by thr Provincial Health Office as the centre of the District Health Office at East Java.

Keywords: Communication, Health, Malaria, Organization, Program

\section{Pendahuluan}

Malaria merupakan salah satu wabah penyakit menular dan banyak menelan korban jiwa di seluruh dunia. Penyakit malaria sangat mempengaruhi tingginya kematian bayi, anak balita, wanita hamil, serta dapat menurunkan produktivitas manusia yang disebabkan anemia serta kejadian luar biasa (KLB). Setiap tahunnya, lebih dari 500 juta manusia terinfeksi malaria dan lebih dari 1 juta di antaranya meninggal dunia.

Menurut catatan Kementrian Kesehatan RI (2010), di Indonesia terdapat 424 kabupaten endemis malaria dari 576 kabupaten yang ada, dan diperkirakan 45\% penduduk Indonesia berisiko tertular malaria. Pada umumnya, lokasi endemis malaria adalah desa-desa yang terpencil dengan kondisi lingkungan yang tidak baik, sarana transportasi dan komunikasi yang sulit, akses pelayanan kesehatan kurang, tingkat pendidikan dan sosial ekonomi masyarakat yang rendah serta perilaku hidup sehat yang kurang baik.

Untuk mengatasi hal tersebut, berbagai upaya telah dilakukan. Antara lain, seperti program Menuju Indonesia Bebas (eliminasi) Malaria. Program eliminasi malaria ini adalah suatu upaya untuk menghentikan penularan malaria setempat dalam satu wilayah geografis tertentu. Namun, bukan berarti tidak ada kasus malaria impor serta sudah tidak ada vektor malaria di wilayah tersebut. Karena itu, tetap dibutuhkan kegiatan kewaspadaan untuk mencegah penularan kembali.

Lebih lanjut, salah satu wilayah yang menjadi target eliminasi (pembebasan) malaria adalah Provinsi Jawa Timur. Dijadikannya Jawa Timur sebagai target eliminasi malaria dikarenakan adanya kasus penderita malaria di beberapa wilayah di Jawa Timur pada tahun-tahun sebelumnya, meskipun tidak sebanyak di beberapa provinsi lainnya di Indonesia. Dengan adanya beberapa kasus penderita malaria ini, Dinas Kesehatan Provinsi Jawa Timur berusaha merespons sehingga dari tahun ke tahun penderita malaria di wilayah ini semakin menurun. 
Bukti penurunan kasus penyakit malaria di Jawa Timur yang semakin menunjukkan kemajuan dari tahun ke tahun, bisa dilihat pada tahun 2013 jumlah kasus malaria di Jawa Timur sebanyak 1.070 orang dan angka ini turun dari tahun 2012 sebanyak 1.320 orang. Dari 1.070 penderita kasus malaria di Jawa Timur, Trenggalek menduduki peringkat yang tertinggi mencapai 155 orang, Kabupaten Malang sebanyak 134 orang dan Banyuwangi sebanyak 130 orang (Pemprov, 2015).

Pada tahun 2014, keberhasilan Provinsi Jawa Timur terus mengalami peningkatan, di mana dari delapan Kabupaten/Kota menjadi 4 kabupaten yang belum mendapatkan sertifikasi eliminasi malaria. Sehingga, pada tahun tersebut Provinsi Jawa Timur telah memperoleh sertifikasi eliminasi malaria dari Kementerian Kesehatan Republik Indonesia sebagai bentuk apresiasi atas keberhasilan tersebut. Pada tahun 2015, hanya tinggal tiga Kabupaten yang belum memperoleh sertifikasi eliminasi malaria, namun ketiga kabupaten ini telah diusulkan mendapatkan sertifikasi eliminasi malaria. Jika hal ini tercapai maka target tahun 2015 sebagai provinsi yang mendapatkan sertifikasi malaria dapat tercapai.

Suksesnya program eliminasi malaria di Provinsi Jawa Timur disebabkan efektivitas komunikasi organisasi yang dilakukan antara Dinas Kesehatan Provinsi dengan Dinas Kesehatan Kabupaten/Kota di Jawa Timur serta Kementerian Kesehatan Republik Indonesia. Sebagai instansi pemerintahan yang berada di bawah naungan pemerintah daerah tingkat provinsi, Dinas Kesehatan Provinsi Jawa Timur memiliki peran ganda yaitu tidak hanya berkoordinasi dengan Dinas Kesehatan Kabupaten/Kota, tetapi juga menjadi penghubung (berkoordinasi) antara pemerintah daerah (Kabupaten/Kota) dengan pemerintah pusat (Kemenkes RI).

Dipilihnya Dinas Kesehatan Provinsi Jawa Timur sebagai lokasi penelitian ini karena berperan sentral sebagai penghubung antara Dinas Kesehatan Kabupaten/Kota dengan Kementerian Kesehatan RI dalam menentukan Kabupaten/Kota untuk mendapatkan sertifikasi eliminasi malaria dari Kementerian Kesehatan RI. Maka dari itu, Dinas Kesehatan Provinsi Jawa Timur sangat bertanggung jawab atas keberhasilan suatu daerah dalam mengeliminasi malaria. Sebab, kesuksesan Provinsi Jawa Timur sebagai wilayah provinsi yang tereliminasi malaria ditentukan oleh Dinas Kesehatan Kabupaten/Kotanya. Sedangkan kesuksesan Dinas 
Kesehatan Kabupaten/Kota sangat bergantung pada Dinas Kesehatan Provinsi Jawa Timur.

Dengan ini, sebagai sebuah organisasi birokrasi pemerintahan, Dinas Kesehatan Provinsi Jawa Timur memiliki manajemen yang jelas untuk mengatur jalannya koordinasi antara atasan dengan bawahan dengan tugas dan fungsi masingmasing yang turut mempengaruhi proses komunikasi organisasi di dalamnya. Hal ini termasuk dalam atau untuk pengolahan informasi, baik itu informasi dari dalam organisasi itu sendiri maupun dari luar organisasi. Dalam program ini, Dinas Kesehatan Provinsi membutuhkan informasi dari Dinas Kesehatan Kabupaten/Kota untuk membuat kebijakan, strategi, perencanaan, dan sebagainya untuk semua hal yang berkaitan dengan program eliminasi malaria. Untuk pengolahan informasi, harus berkoordinasi dengan Dinas Kesehatan Kabupaten/Kota yang mana dalam hal ini juga membutuhkan manajemen di Dinas Kesehatan Provinsi Jawa Timur sendiri.

Melihat dari fenomena tersebut, peneliti menggunakan pendekatan teori Menajemen Weber tentang birokrasi (managerialism and Weber's theory of bureaucracy). Dalam Littlejohn \& Foss (2011) dikemukakan bahwa dalam teori ini, Weber memberikan definisi bahwa sebuah organisasi merupakan sebuah sistem kegiatan interpersonal yang memiliki maksud tertentu yang dirancang untuk menyelaraskan tugas-tugas personal atau individu. Hal ini tidak dapat dilakukan tanpa adanya kewenangan, spesialisasi/pengkhususan, dan peraturan.

Selain itu, karena penelitian ini fokus pada pengolahan informasi komunikasi organisasi yang melibatkan Dinas Kesehatan Provinsi dan Dinas Kesehatan Kabupaten/Kota di Jawa Timur, maka penelitian ini juga menggunakan pendekatan teori proses berorganisasi (the process of organizing) dari Karl Weick. Littlejohn \& Foss (2011) menjelaskan bahwa teori tentang berorganisasi sangat penting dalam bidang komunikasi sebagai sebuah dasar bagi pengorganisasian manusia dan memberikan sebuah dasar pemikiran untuk memahami bagaimana manusia berorganisasi. Menurut Weick, semua informasi dari lingkungan sekitar bersifat samarsamar atau ambigu pada berapa tingkatan, dan kegiatan berorganisasi dirancang untuk mengurangi ketidakpastian. Untuk menghilangkan ketidakpastian memerlukan proses. Proses untuk menghilangkan ketidakpastian tersebut merupakan proses yang 
berkembang dengan tiga bagian, yaitu mengolah (enactment), memilih (selection), dan menyimpan (retention).

\section{Tinjauan Pustaka}

\section{Komunikasi Organisasi}

Menurut Pace \& Faules (2001), komunikasi organisasi dapat didefinisikan sebagai petunjuk dan penafsiran pesan di antara unit-unit komunikasi yang merupakan bagian dari suatu organisasi tertentu. Suatu organisasi terdiri dari unit-unit komunikasi dalam hubungan-hubungan hierarkis antara yang satu dengan lainnya dan berfungsi dalam suatu lingkungan. Menurut Hardjana (2016), struktur organisasi terbentuk sebagai konsekuensi dari pembagian kerja dan merupakan struktur kewenangan yang menunjukkan hubungan saling ketergantungan antar seluruh elemen organisasi. Istilah struktur komunikasi diartikan sebagai saluran-saluran hierarkis yang digunakan untuk mengalirkan pesan komunikasi organisasi, yakni garis-garis kewenangan yang menunjukkan keteraturan arus informasi mengalir ke seluruh organisasi. Arus pesanpesan komunikasi formal mengalir melalui garis-garis kewenangan hierarkis dengan prinsip mata rantai berjenjang (scalar chain). Dengan demikian untuk mencapai tujuan organisasi, arus pesan komunikasi mengalir melalui saluran struktur komunikasi formal ke empat arah, yaitu ke bawah, ke atas, ke samping, dan menyilang.

Lebih lanjut, struktur komunikasi organisasi mempengaruhi bentuk komunikasi dalam sebuah organisasi. Secara umum, bentuk komunikasi organisasi meliputi dua arus atau bentuk, yaitu arus komunikasi dalam organisasi meliputi komunikasi vertikal dan komunikasi horizontal (Fajar, 2009). Selain bentuk komunikasi vertikal dan horizontal dalam komunikasi organisasi, terdapat pula komunikasi diagonal. Adapun menurut Hardjana (2016), komunikasi diagonal terjadi di antara dua orang yang berbeda jenjang kedudukan dalam struktur hierarkis dan berbeda divisi atau jalur fungsi.

Selain itu,_menurut Barnard (1938:217), komunikasi mempunyai dua fungsi dalam kegiatan organisasi, yaitu pertama, memotivasi atau memelihara semangat untuk menyumbangkan energi kepada organisasi. Kedua, untuk memelihara konsistensi tujuan agar arah kegiatan organisasi tidak menyimpang. Artinya, dalam mencapai tujuan organisasi dibutuhkan dua jenis komunikasi, yakni persuasi dan 
motivasi karyawan serta koordinasi dan kontrol sehingga kesamaan tujuan tetap terpelihara. Dalam perkembangannya, fungsi komunikasi mencakup urusan yang lebih luas lagi tidak hanya terbatas pada fungsi motivasi dan koordinasi (Hardjana, 2016:138).

\section{Manajemen dan Teori Birokrasi}

Max Weber (1864-1920) melahirkan banyak karya, salah satunya adalah teori birokrasi. Ide Weber yang dikembangkan pada awal abad ke 20 itu, adalah bagian dari apa yang sekarang dikenal dengan "teori organisasi klasik". Weber mencoba mengetahui cara terbaik bagi organisasi dalam mengatur kerumitan kerja individu dengan maksud atau tujuan yang biasa terjadi (Littlejohn \& Foss, 2011: 295). Dalam Littlejohn dan Foss (2011), Weber memberikan definisi bahwasanya sebuah organisasi sebagai suatu sistem kegiatan interpersonal yang memiliki tujuan tertentu dan didesain untuk menyesuaikan tugas-tugas setiap orang. Hal ini tidak bisa dikerjakan tanpa adanya kewenangan, spesialisasi/pengkhususan, dan peraturan. Kewenangan hadir bersamaan dengan kekuasaan, tetapi dalam organisasi, kewenangan harus "sah" atau disahkan secara formal oleh organisasi. Efektivitas sebuah organisasi tergantung pada tingkatan pemberi peraturan kekuasaan resmi (legitimate power) oleh organisasi. Dengan kata lain, para manajer memiliki kekuasaan bukan karena faktor usia, kecerdasan, bujukan, atau kekuatan fisik, tetapi karena organisasi memberikan otoritas.

\section{Teori Proses Berorganisasi}

Teori proses berorganisasi yang dikemukakan oleh Karl Weick sangat penting dalam keilmuan komunikasi sebab teori ini menjadikan komunikasi sebagai dasar bagi pengorganisasian manusia dan juga memberikan dasar pemikiran untuk memahami bagaimana manusia berorganisasi. Dalam teori ini dijelaskan bahwa organisasi bukanlah susunan yang terbentuk oleh posisi dan peranan, tetapi terbentuk oleh aktivitas komunikasi. Maka dari itu, lebih pantas dikatakan "Berorganisasi" daripada "Organisasi”, sebab organisasi sendiri merupakan suatu yang dicapai oleh manusia dengan proses komunikasi yang berkelanjutan. Ketika manusia berinteraksi sehari-hari, kegiatannya dapat menciptakan organisasi. Semua perilaku anggota organisasi dihubungkan karena perilaku seseorang bergantung pada perilaku orang lain (Littlejohn \& Foss, 2011: 297). 
Lebih lanjut, dalam Littlejohn \& Foss (2011), kegiatan berorganisasi berfungsi untuk mengurangi ketidakpastian informasi. Istilah kunci teoritis Weick adalah equivocality, yang berarti ketidakpastian, kesulitan, ambiguitas, dan kurangnya keterdugaan. Menurut Weick, semua informasi dari lingkungan sekitar bersifat samarsamar atau ambigu pada beberapa tingkatan, dan kegiatan organisasi dirancang untuk mengurangi ketidakpastian ini. Tidak semua interaksi sama pentingnya dalam mengurangi ketidakpastian, tetapi setiap usaha berkontribusi.

Proses penghilangan kesamaran atau ketidakpastian ini merupakan proses yang berkembang dengan tiga bagian, yaitu pembuatan (enactment), pemilihan (selection), dan penyimpanan (retention). Pembuatan adalah definisi tentang situasi, atau menyatakan adanya informasi yang samar-samar dari luar. Proses yang kedua adalah pemilihan yang mana anggota organisasi menerima beberapa informasi sebagai sesuatu yang relevan dan menolak informasi lain. Pemilihan mempersempit bidang, menghilangkan pilihan yang tidak ingin dihadapi oleh pelaku pada saat itu. Oleh karena itu, proses ini menghilangkan lebih banyak kesamaran dari informasi awal. Terakhir dari proses berorganisasi adalah penyimpanan, di mana informasi akan disimpan dan digunakan di masa yang akan datang. Informasi yang disimpan tersebut akan digabungkan pada kesatuan informasi yang sudah ada dalam menjalankan organisasi (Littlejohn \& Foss, 2011: 298).

\section{Metode Penelitian}

Penelitian ini menggunakan metode penelitian kualitatif dengan pendekatan studi kasus. Penelitian dilakukan di Dinas Kesehatan Provinsi Jawa Timur pada bulan September sampai November 2015. Sementara subjek penelitiannya ialah beberapa pengelola program eliminasi malaria di Dinas Kesehatan Provinsi Jawa Timur yang berjumlah lima orang. Pengumpulan data dilakukan dengan wawancara mendalam dan metode dokumenter dengan menggunakan teknik snowball sampling. Analisis data peneliti melakukannya bersamaan dengan proses pengumpulan data. Setelah mereduksi data ketika data-data terkumpul, peneliti memilih hal-hal pokok yang sesuai dengan fokus penelitian. Kemudian menarik kesimpulan dengan menarik keterkaitan antara data yang sudah direduksi oleh peneliti dan teori yang digunakan. 


\section{Hasil Penelitian dan Pembahasan}

\section{Pengorganisasian Komunikasi Organisasi Antara Dinas Kesehatan Provinsi dan Kabupaten/Kota}

Adanya kepatuhan dan pemahaman semua komponen pelaku organisasi program eliminasi malaria terhadap kewenangan, spesialisasi/pengkhususan, dan peraturan yang menyebabkan suksesnya program eliminasi malaria di Provinsi Jawa Timur, termasuk dalam menjalankan komunikasi organisasi antara Dinas Kesehatan Provinsi dengan Dinas Kesehatan Kabupaten/Kota. Sehingga, menyebabkan semua sistem berjalan sebagai mana mestinya dan tidak ada tumpang tindih dalam menjalankan peran masing-masing, baik atasan maupun bawahan dengan aturanaturan yang dijadikan pedoman.

Weber dalam Littlejohn dan Foss (2011) memberikan definisi bahwa organisasi adalah sistem kegiatan interpersonal yang memiliki tujuan tertentu yang dirancang untuk menyelaraskan tugas-tugas individu. Hal ini tidak dapat dilakukan tanpa adanya kewenangan, spesialisasi/pengkhususan, dan peraturan. Kewenangan hadir bersamaan dengan kekuasaan, tetapi dalam organisasi, kewenangan harus "sah" atau disahkan secara formal oleh organisasi. Efektivitas organisasi tergantung pada pemberi manajemen kekuasaan resmi (legitimate power) oleh organisasi. Dengan kata lain, para manajer memiliki kekuasaan bukan karena faktor usia, kecerdasan, bujukan, atau kekuatan fisik, tetapi karena organisasi memberikan kewenangan.

Dikaitkan dengan temuan penelitian tersebut, pengelola program eliminasi malaria di Dinas Kesehatan Provinsi Jawa Timur benar-benar menjalankan sebuah sistem organisasi dengan menempatkan sesuatu pada tempatnya. Dalam artian, semua komponen pelaku organisasi menjalankan peran masing-masing sesuai dengan peraturan yang diperintahkan oleh pemegang otoritas. Pemegang otoritas juga menempatkan dirinya sebagai pemegang otoritas dengan tetap mengikuti aturan yang telah disetujui bersama.

Setiap jenjang manajemen memiliki kewenangan resmi, dan hanya kepala organisasi yang memiliki kewenangan penuh dan menyeluruh. Walaupun Weber mengatakan bahwa manajer harus ditunjuk berdasarkan kualifikasinya, kepala organisasi jarang sekali dipilih atas dasar ini (Littlejohn \& Foss 2011). Begitu pula dengan program eliminasi malaria ini, setiap lapisan manajemen memiliki peran dan 
kekuasaan masing-masing. Semakin tinggi otoritas perannya, maka tanggung jawabnya semakin besar, begitu pula sebaliknya. Pemberian otoritas juga melihat dari kualifikasi setiap individu terkait hal-hal yang dasar dan kemampuan, hal ini demi efektifnya sebuah program.

Pemberian otoritas dalam setiap program juga merupakan bagian dari spesialisasi terhadap tugas-tugas yang akan diberikan pada individu. Menurut Weber, setiap individu dibagi atas tugas masing-masing dan individu tersebut mengetahui tugas di dalam organisasi. Begitu pula dengan spesialisasi tugas-tugas di program eliminasi malaria di Dinas Kesehatan Provinsi Jawa Timur yang disesuaikan dengan setiap individu, sehingga setiap individu memahami tugas-tugas yang akan dikerjakan karena semua individu dalam program ini memiliki latar belakang dari ilmu kesehatan. Selain itu, diadakan pelatihan untuk menjadi fasilitator eliminasi malaria terhadap pengelola program eliminasi malaria di Dinas Kesehatan Kabupaten/Kota. Begitu pula dengan pemegang otoritas tertinggi juga mengetahui orang-orang yang berkompeten untuk mengelola tugas-tugas tertentu.

Aspek ketiga dari birokrasi adalah tuntutan aturan (rules). Apa yang membuat koordinasi organisasi menjadi mungkin adalah implementasi regulasi yang mengatur perilaku setiap orang. Aturan-aturan organisasi harus rasional yang berarti bahwa aturan-aturan tersebut dirancang untuk mencapai tujuan organisasi (Littlejohn \& Foss, 2011). Aturan inilah yang juga memegang peranan penting terhadap suksesnya program eliminasi malaria di Provinsi Jawa Timur, terutama di Dinas Kesehatan Provinsi Jawa Timur sebagai sentral Dinas Kesehatan se-Jawa Timur. Sesuai dengan yang dijelaskan di atas, aturan-aturan tersebut ada yang berasal dari Kementrian Kesehatan RI sebagai aturan baku yang disesuaikan dengan semua Dinas Kesehatan di seluruh Indonesia, dan aturan yang dirancang sendiri oleh para pengelola eliminasi malaria di Dinas Kesehatan Provinsi Jawa Timur yang mengacu pada aturan yang dibuat oleh Kementerian Kesehatan.

Aturan-aturan yang diciptakan tersebut benar-benar diimplementasikan dan dipatuhi oleh semua komponen pengelola program. Aturan-aturan tersebut bertujuan untuk memberikan arah dalam menjalankan setiap program, baik itu dari atasan kepada bawahan, atau bawahan dalam memberikan laporan terhadap atasan. Sehingga, program eliminasi program eliminasi malaria benar-benar berjalan efektif. 
Seperti yang dikatakan Littlejohn dan Foss (2011), model birokrasi Weber menggambarkan dengan baik metafora mesin dari organisasi. Artinya, para pengelola di program ini harus berkoordinasi untuk mencapai tujuan yang ditetapkan sesuai dengan aturan-aturan yang ada. Selain itu antara otoritas, spesialisasi, dan regulasi merupakan komponen yang tidak bisa dipisahkan bagaikan sistem sebuah mesin, jika salah satu komponen tersebut rusak maka mesin tersebut tidak akan berjalan.

\section{Pengolahan, Penyaringan, dan Penyimpanan Informasi dalam Komunikasi Organisasi Antara Dinas Kesehatan Provinsi dan Kabupaten/Kota}

Para pengelola program eliminasi malaria di Dinas Kesehatan Provinsi Jawa Timur dalam mengolah (menetapkan), memilih, dan menyimpan informasi untuk mengurangi ketidakpastian informasi dari Dinas Kesehatan Kabupaten/Kota dilakukan dengan hati-hati. Semua informasi tersebut benar-benar diteliti validitasnya, bahkan sampai datang ke korban penyakit malaria. Kehati-hatian tersebut bukan berarti karena tidak ada kepercayaan terhadap para pengelola program eliminasi malaria di Dinas Kesehatan Kabupaten/Kota sebagai pemberi informasi. Tetapi, sebuah upaya untuk menghindari adanya keteledoran dalam menyampaikan informasi. Hal ini dilakukan demi kesuksesan program eliminasi malaria ini, yang mana dalam hal ini informasi sebagai ujung tombak berjalan dan suksesnya program tersebut.

Dikaitkan dengan teori Weick dalam Littlejohn \& Foss (2011), dalam teori ini dijelaskan bahwa organisasi bukanlah susunan yang terbentuk oleh posisi dan peranan, tetapi terbentuk oleh aktivitas komunikasi. Kaitan antara temuan penelitian dengan teori yang diciptakan Weick tentang berorganisasi ialah bahwa adanya pengolahan informasi dari Dinas Kesehatan Kabupaten/Kota oleh Dinas Kesehatan Provinsi Jawa Timur menunjukkan adanya aktivitas organisasi di antara kedua instansi pemerintahan di bidang kesehatan tersebut. Karena adanya pengolahan informasi atau pesan menunjukkan adanya aktivitas komunikasi, sedangkan pesan adalah inti dari komunikasi. Jika tidak ada informasi atau pesan, maka komunikasi tidak akan ada. Apalagi menurut teori ini, organisasi bukanlah susunan yang dibentuk oleh posisi dan peranan, tetapi oleh aktivitas komunikasi. Hal ini menunjukkan bahwa komunikasi adalah ujung tombak dari proses berorganisasi sebab kesuksesan sebuah organisasi ditentukan oleh proses komunikasinya. 
Lebih lanjut, kegiatan pengolahan informasi dari Dinas Kesehatan Kabupaten/Kota yang dilakukan oleh Dinas Kesehatan Provinsi Jawa Timur yang bertujuan untuk mengurangi ketidakpastian informasi karena takutnya ada kesalahan dalam penyampaian informasi, sehingga informasi tersebut dianggap ambigu. Hal ini sesuai dengan yang dikatakan Weick, semua informasi dari lingkungan sekitar bersifat samar-samar atau ambigu pada beberapa tingkatan, dan kegiatan organisasi dirancang untuk mengurangi ketidakpastian ini. Kehati-hatian Dinas Kesehatan Provinsi Jawa Timur dalam mengolah informasi yang didapatkan memerlukan proses karena proses pengolahan informasi tersebut melibatkan dua instansi. Dikaitkan dengan teori ini, untuk mengurangi ketidakpastian informasi menurut Weick ada tiga proses, yaitu pembuatan (enactment), pemilihan (selection), dan penyimpanan (retention).

Proses pembuatan informasi menurut Weick adalah definisi tentang keadaan, atau menyatakan adanya informasi yang tidak jelas dari luar. Hal ini dilakukan oleh Dinas Kesehatan Provinsi Jawa Timur saat menerima laporan data-data tentang malaria, baik itu untuk menilai suatu daerah yang mengajukan untuk mendapatkan sertifikasi, maupun informasi tentang kegiatan pemberantasan malaria di suatu daerah. Untuk menghilangkan ambiguitas informasi khususnya informasi untuk penilaian eliminasi malaria di Kabupaten/Kota, Dinas Kesehatan Provinsi Jawa Timur tidak langsung menerima informasi begitu saja, bahkan jika diperlukan langsung datang ke daerah yang dicurigai ada endemis malaria untuk membenarkan informasi tersebut.

Proses yang kedua menurut teori ini ialah penyaringan informasi yang mana peserta organisasi mengambil beberapa informasi yang sesuai dan menolak informasi lain yang tidak sesuai. Dalam pemilihan informasi yang didapatkan, Dinas Kesehatan Provinsi Jawa Timur menganalisis dan menilai data-data yang diterima setelah melakukan cross-check kebenaran data tersebut. Dari analisis data dan penilaian data inilah informasi dipilih untuk diterima atau ditolak. Oleh karena itu, proses ini menghilangkan lebih banyak kesamaran dari informasi awal. Data-data yang diterima tersebut akan usulkan ke Kementerian Kesehatan untuk dinilai lagi validitasnya agar daerah yang memberikan informasi mendapatkan sertifikasi eliminasi malaria. Sedangkan informasi untuk kegiatan eliminasi malaria di Kabupaten/Kota dianalisis dan dinilai sendiri oleh pihak provinsi kemudian ditentukan langkah apa saja yang akan dikerjakan. 
Sedangkan yang terakhir dari proses menjalankan organisasi ialah penyimpanan informasi, di mana informasi tersebut akan disimpan untuk penggunaan di masa yang akan datang. Informasi yang disimpan tersebut akan digabungkan pada kesatuan informasi yang sudah ada dalam menjalankan aktivitas organisasi (Littlejohn \& Foss, 2011). Proses penyimpanan informasi dari Dinas Kesehatan Kabupaten/Kota pada program eliminasi malaria di Dinas Kesehatan Provinsi Jawa Timur setelah terjadinya pembuatan dan pemilihan informasi. Adapun prosesnya seperti yang telah dijelaskan di atas yaitu tidak langsung menerima informasi begitu saja. Setelah itu, menganalisis dan menilai informasi, kemudian informasi inilah yang disimpan untuk keperluan di masa yang akan datang. Keperluan tersebut, untuk World Health Organization (WHO) jika berkunjung ke Jawa Timur, serta keperluan lain seperti dokumentasi dan sebagainya.

Proses pengurangan ketidakpastian informasi oleh para pengelola program eliminasi malaria di Dinas Kesehatan Provinsi Jawa Timur merupakan siklus yang saling berhubungan satu sama lain. Jika salah satu siklus dari proses ini tidak berjalan maka proses pengurangan ketidakpastian ini akan gagal, karena pembuatan, pemilihan, dan penyimpanan informasi ini saling terkait satu sama lain dengan aturan-aturan yang ditetapkan oleh Kementerian Kesehatan RI. Seperti yang dikatakan dalam Littlejohn \& Foss (2011), saat manusia berkomunikasi untuk mengurangi ketidakpastian, mereka menjalani sebuah rangkaian siklus perilaku (behavior cycles), atau kebiasaan yang memungkinkan kelompok menjelaskan segala sesuatunya. Dalam sebuah siklus perilaku, tindakan anggota diatur oleh aturan tindakan (assembly rules) yang menuntun pilihan kebiasaan yang digunakan untuk menyelesaikan proses yang sedang dijalankan (pembuatan, pemilihan, atau penyimpanan).

\section{Kesimpulan}

Berdasarkan uraian deskripsi dan analisis yang telah disusun sesuai rumusan masalah, maka peneliti dapat menarik kesimpulan bahwa suksesnya program eliminasi malaria di Provinsi Jawa Timur tidak lepas dari pengorganisasian yang dilakukan dengan pembagian tiga komponen yaitu kewenangan, spesialisasi/pengkhususan, dan peraturan. Ketiga komponen tersebut berjalan sebagai mana mestinya. Hal ini disebabkan oleh patuh dan pahamnya semua komponen 
anggota organisasi program eliminasi malaria terhadap kewenangan, spesialisasi/pengkhususan, dan peraturan yang menyebabkan suksesnya program eliminasi malaria di Provinsi Jawa Timur termasuk dalam menjalankan komunikasi organisasi antara Dinas Kesehatan Provinsi dengan Kabupaten/Kota. Sehingga, semua sistem berjalan sebagai mana mestinya dan tidak ada tumpang tindih dalam menjalankan peran masing-masing baik atasan maupun bawahan dengan aturan-aturan yang dijadikan pedoman.

Selain itu, informasi merupakan ujung tombak suksesnya program eliminasi malaria ini. Maka dari itu, para pengelola program eliminasi malaria di Dinas Kesehatan Provinsi Jawa Timur dalam mengelola (menetapkan), menyaring, dan menyimpan informasi dari Dinas Kesehatan Kabupaten/Kota dilakukan dengan hatihati, semua informasi tersebut benar-benar diteliti validitasnya bahkan sampai datang ke korban penyakit malaria. Maka dari itu, informasi yang datang dari Dinas Kesehatan Kabupaten/Kota tidak langsung diterima begitu saja. Tetapi disaring atau dipilih terdahulu kemudian disimpan. Tujuan pengurangan ketidakpastian informasi oleh para pengelola program eliminasi malaria di Dinas Kesehatan Provinsi Jawa Timur merupakan siklus yang saling berhubungan satu sama lain. Jika salah satu siklus dari proses ini tidak berjalan maka proses pengurangan ketidakpastian ini akan gagal.

\section{Daftar Rujukan}

\section{Buku}

Direktorat Pengendalian Penyakit Bersumber Binatang. (2010). Menuju Indonesia Bebas

Malaria Kementrian Kesehatan RI. Direktorat Jenderal Pengendalian Penyakit \& Penyehatan Lingkungan.

Fajar, M. (2009). Ilmu Komunikasi Teori \& Praktik. Yogyakarta: Graha Ilmu.

Hardjana, A. (2016). Komunikasi Organisasi Strategi dan Kompetensi. Jakarta: Penerbit Buku Kompas.

Littlejohn, S. W. \& Foss, K. A. (2011). Theories of Human Communication, Tenth Edition New Mexico: Waveland Press.

Miller, K. (2005). Communication Theories Prespective, Processes, and Contexts second edition, Singapore. Mc Graw Hill. 
Pace, R. W. \& Faules, F. D. (2001). Komunikasi Organisasi Strategi Meningkatkan Kinerja Perusahaan. Bandung: Remaja Rosdakarya.

\section{Artikel Daring}

Pemprov Jatim. (2015). "Hentikan Penularan, Jatim Raih Sertifikasi Eliminasi Malaria”, http://www.jatimprov.go.id/site/hentikan-penularan-jatim-raihsertifikasi-eliminasi malaria yang diakses 3 Agustus 2015 pukul 12:30 WIB. 